\title{
Analisis Kemampuan Pemerintah Daerah Dalam Penataan
} Minimarket

\section{(Studi Implementasi Peraturan Bupati Kabupaten Ciamis No 51 Tahun 2014 Tentang Pendirian Toko Modern Serta Perlindungan Usaha Kecil, Warung/Toko Dan Pasar Tardisional)}

\author{
Ombi Romli ${ }^{1}$ \\ ${ }^{1}$ Program Studi Ilmu Pemerintahan, Fakultas Hukum dan Sosial, Universitas Mathla'ul \\ Anwar, Jalan Raya Labuan KM 23, Cikaliung, Saketi, Sindanghayu, Saketi, Kabupaten \\ Pandeglang, Banten 42273
}

\begin{abstract}
The existence of minimarkets and their rapid growth lead to unhealthy market competition which has an impact on the weakening of the traditional market climate and turns off the bankruptcy business. The Regional Government of Ciamis Regency issued a regulation in the form of Regulations from the Regent of Ciamis Regency No. 51 of 2014 concerning the establishment of Modern Stores and the Protection of Small Businesses, Stalls / Shops and Traditional Markets in order to minimize the imbalance of competition. The purpose of this research is to analyze the ability of local government in structuring minimarket, this research uses the analysis base proposed by(Jones, 1996)which consists of aspects of organization, interpretation, and application. The results of the study show that the ability of the local government of Ciamis Regency in the minimarket arrangement is still very weak with all the limitations.
\end{abstract}

Keywords: Implementation, Local Government, Structuring Minimarket, Ciamis Regency

\section{Pendahuluan}

Kehadiran

merupakan angin segar bagi perkembangan iklim waralaba di Indonesia yang mendapat respon positif dari masyarakat sebagai penikmat layanan yang diberikan. Tidak hanya tersebar di kota-kota besar, kehadiran minimarket saat ini sudah menjangkau seluruh sendi wilayah yang keeradaannya mudah ditemui sampai pada pelosok desa.

Masuknya minimarket sampai pada pelosok desa disinyalir karena luasnya jaringan perusahaan dalam mengembangkan sayap binsisnya. Di samping semakin ketatnya iklim persaingan bisnis pada pusat-pusat kota maupun pada wilayah peripheral di perkotaan sudah banyak hypermarketdan supermarket yang berdiri. Tidak dipungkiri kehadiran mini market pada satu sisi akan dapat meningkatkan Pendapatan Asli Daerah (PAD), menyerap lapangan pekerjaan baru, meningkatkan pertumbuhan ekonomi daerah, alih pengetahuan dan teknologi pemasaran barang dan jasa serta kemudahan akses bagi warga untuk mendapatkan beragam produk bermutu dengan standar pelayanan yang tinggi. Namun, pada sisi lain, kehadiran 
minimarket ini dapat mengganggu eksistensi pasar tradisional dan pelaku pasar tradisional yang selama ini menggantungkan kehidupan ekonomi pada sektor ritel, persaingan ekonomi tidak sehat antara pelaku-pelaku bisnis, ancaman pengalihan fungsi lahan pemukiman maupun pertanian serta tata ruang kabupaten dan kawasan.

Koneks minimarket secara umum dibedakan menjadi dua diantaranya : 1 . Minimarket berjaringan, 2. Minimarket tidak berjaringan. Minimarket berjaringan adalah kegiatan usaha di bidang minimarket melalui satu kesatuan manajemen dan sistem pendistribusian barang ke outlet yang merupakan jaringannya. Minimarket berjaringan dimaknai sebagai usaha minimarket yang merupakan bagian dari sebuah brand dagang tertentu yang meliputi berbagai wilayah, daerah, provinsi maupun manca negara. Minimarket berjaringan ini termasuk minimarket yang sudah terkenal secara nasional seperti Alfamart, Indomaret, Alfamidi, Yogyamart. Sedangkan minimarket tidak berjaringan dimaksudkan sebagai usaha minimarket yang tidak memiliki jaringan bisnis atau cabang-cabang tertertentu pada wilayah lainnya. Minimarket tidak berjaringan ini dapat dikatakan sebagai usaha tunggal yang melaksanakan usaha minimarket.

Luasnya jaringan tidak sedikit menimbulkan dampak negatif yang timbul dari luasnya jaringan persebaran minimarket (Alfamart dan Indomart) secara langsung dapat mematikan usaha kecil disekitarnya, dan melemahkan pasar-pasar tradisional yang secara langsung menghidupi perputaran roda perekonomian kerakyatan. Realitas tersebut secara sporadis mendesak dan menyudutkan pasar tradisional, pedagang tradisional, kios, warung maupun toko yang memiliki keterbatasan modal dan kemampuan sumber daya manusia. Persaingan yang tidak seimbang dan strategi perdangan yang jauh merupakan fakta yang tidak terelakan, bawasanya Pasar tradisional dan pedagang tradisional saat ini masih bergulut dengan masalahnya seperti penurunan omzet penjualan manajemen pasar yang buruk, minimnya fasilitas infrastruktur dari pasar tradisional, banyaknya pungutan retribusi dan kurangnya bantuan permodalan yang tersedia untuk pedagang di tengah gempuran pasar moderen tersebut. (Arno \& Aqidah, 2018).

Ironisnya prilaku konsumen saat ini kurang mendukung berkembangnya iklim usaha kerakyatan, terbukti dengan ramainya retail-ritail baik di pusat kota maupun desa. Ihwal tersebut karena pola perilaku konsumen yang menginginkan adanya layanan baik berupa kemudahan dan kenyamanan pasar moderen tau retail menjadikan pasar tradisional dan warung kelontong semakin sulit untuk bertahan hidup.

Minat masyarakat untuk berbelanja di minimarket juga meningkat, ihwal tersebut dikarenakan pasar modern (minimarket) lebih rapi, bersih dan praktis dari pada pasar tradisional, meskipun tak sedikit pula masyarakat yang memilih loyal terhadap pasar tradisional. Sejatinya perubahan perilaku konsumen tersebut merupakan adanya pergeseran dari kebutuhan fungsional menjadi kebutuhan psikologis kebutuhan fungsional yang berhubungan langsung dengan bentuk atau penampilan dari produk, sedangkan kebutuhan psikologis yaitu kebutuhan 
yang diasosiasikan dengan kebutuhan yang bersifat mental dari konsumen yang dapat terpenuhi dengan membeli sebuah produk.

$$
\text { Keadaan di atas tentunya }
$$
memiliki pengaruh buruk terhadap keberlangsungan pasar tradisional atau warung kelontong. Salah satu bukti buruknya iklim usaha tersebut yaitu adanya pendirian minimarket yang berjarak hanya 100 meter dari lokasi pasar tradisional, hal tersebut secara langsung menyalahi Peraturan Bupati Kabupaten Ciamis dan dilain sisi masih terdapat adanya minimarket yang hanya menggunakan izin mendirikan bangunan tanpa adanya izin usaha yang telah namun telah beroprasional.

Meskipun banyak faktor lain yang mengancam akan keberlangsungan pasar tradisional sebenarnya bukan saja karena hadirnya pasar modern, akan tetapi hampir semua pasar tradisional di Indonesia masih berjuang dengan masalah internal yang ada seperti manajemen pasar yang buruk, minimnya fasilitas infrastruktur dari pasar tradisional, banyaknya pungutan retribusi dan kurangnya bantuan permodalan yang tersedia untuk pedagang (Arno \& Aqidah, 2018).

Fakta persebaran minimarket dan dampaknya terhadap perkembangan pasar tradisonal dan usaha kecil seperti warung kelontong telah terjadi di Kabupaten Ciamis, Jawa Barat semakin mengkhwatirkan. Ihwal tersebut membuat pemerintah Kabupaten Ciamis menerbitkan regulasi berupa Peraturan Bupati Ciamis Nomor 51 Tahun 2014 Tentang Pendirian Toko Moderen Serta Perlindungan Usaha Kecil, Warung/Toko dan Pasar Tradisional; penataan pasar moderen termasuk minimarket termasuk di dalamnya penyelenggaraan kemitraan dengan pasar tradisional dan pelaku usaha lainnya.

$$
\text { Regulasi berupa Peraturan }
$$

Bupati tersebut pada aplikasinya membutuhkan profsionalisme aparatur dalam menegakan peraturan tersebut guna tercapainya tujuan dalam penataan keberadaan miimarket di Kabupaten Ciamis. Guna mengupas kemampuan pemerintah daerah daerah dalam penataan zonasi minimarket di Kabupaten Ciamis (Studi Pada Implementasi Peraturan Bupati Kabupaten Ciamis No 51 Tahun 2014 Tentang Pendirian Toko Modern Serta Perlindungan Usaha Kecil, Warung/Toko Dan Pasar Tardisional) peneliti menggunakan teori yang dikemukakan oleh(Jones, 1996) yang terdiri dari aspek Organisasi, interpretasi, dan aplikasi. Ketiga aspek tersebut diyakini peneliti secara relevan dapai menganalisis kemampuan pemerintah daerah dalam menjalankan fungsinya terkait dengan implementasi peraturan Bupati tersebut.

Organisasi berbicara terkait dengan penetapan atau pengaturan sumberdaya, unit dan metode-metode untuk menjadikan kebijakan berjalan efektif. Kemudian interpretasi atau penerjemahan bermakna bahwa pelaksana kebijakana harus mampu menjalankan program sesuai dengan petunjuk teknis dan petunjuk pelaksana sebagai arah untuk mencapai tujuan yang diharapkan. Interpretasi juga berbicara tentang penerjemahan bahasa program yang biasanya dibuat dalam statuta organisasi yang akseptable, rencana kelayakan dan arah dari program. Adapun aplikasi atau penerapan berbicara tentang pembuatan prosedur kerja yang jelas agar program kerja dapat 
berjalan sesuai dengan jadwal kegiatan (timetable) sehingga tidak berbenturan dengan program lainnya. Aplikasi juga berbicara tentang syarat layanan, pembayaran atau kesepakatan lainnya yang sesuai dengan tujuan dan instrumen.

Penelitian ini bertujuan untuk mengetahui kemampuan Pemerintah Daerah Kabupaten Ciamis dalam mengimplentasikan Peraturan Bupati Kabupaten Ciamis No 51 Tahun 2014 Tentang Pendirian Toko Modern Serta Perlindungan Usaha Kecil, Warung/Toko Dan Pasar Tardisional

\section{Metode Penelitian}

Penelitian ini menggunakan metode kualitatif yaitu prosedur penelitian yang menghasilkan data deskripsi berupa kata-kata tertulis atau lisan dari orang-orang dan perilaku yang diamati (Moleong, 2008). (Creswel, 2015) menyatakan bahwa "metode kualitatif dipilih karena penelitian ini menekankan pada proses bukan pada hasil".

Bogdan dan Taylor dalam (Moleong, 2008) mendefinisikan penelitian kualitatif sebagai prosedur penelitian yang menghasilkan data deskriptif berupa kata-kata tertulis atau lisan dari orang-orang dan perilaku yang diamati dari fenomena yang terjadi. Lebih lanjut (Moleong, 2008) mengemukakan bahwa penelitian deskriptif menekankan pada data berupa kata-kata, gambar, dan bukan angkaangka yang disebabkan oleh adanya penerapan metode kualitatif. Selain itu, semua yang dikumpulkan berkemungkinan menjadi kunci terhadap apa yang sudah diteliti. Hal tersebut agar dapat memberikan gambaran mendalam terkait kemampuan pemerintah daerah daerah dalam penataan zonasi minimarket di Kabupaten Ciamis (Studi Pada Implementasi Peraturan Bupati Kabupaten Ciamis No 51 Tahun 2014 Tentang Pendirian Toko Modern Serta Perlindungan Usaha Kecil, Warung/Toko Dan Pasar Tardisional).

Data primer dalam penelitian ini diperoleh dengan cara observasi dan wawancara secara mendalam (in-depth interview), yaitu pengumpulan data dengan cara mengadakan tanya jawab secara langsung dan lisan kepada pihakpihak yang berkaitan dengan masalah yang diteliti, dengan narasumber di lokasi penelitian. Lebih lanjut bahwa teknik analisis data yang digunakan dalam penelitian ini adalah menggunakan langkah-langkah seperti yang dikemukakan oleh (Bungin, 2012), yaitu pengumpulan data, reduksi data, display data, verifikasi dan penegasan kesimpulan. Sedangkan teknik pemeriksaan kredibilitas/derajat kepercayaan yang digunakan dalam penelitian ini adalah teknik trianggulasi sumber

\section{Hasil danPembahasan}

\section{Analisis Kemampuan Pemerintah Daerah Dalam Penataan Minimarket Dimensi Organsasi : Kompeksitas Kewenanagan dan LemahnyaSDM}

Dasar keberhasilan dalam setiap tindak tanduk pemerintah yang terfregmentasi dalam Satuan Kerja Perangkat Daerah (SKPD) secara tidak langsung merupakan pengejawantahan sumber daya organisasi. Bahwasanya Sumber daya organisasi menjadi pembahasan penting dalam implementasi kebijakan publik karena pada dasarnya kebijakan publik tersebut dilaksanakan oleh aktor dalam struktur yang birokratis. Manunisa (man) dalam struktur organisasi baik yang bercorak formal maupun swasta menyadari bahwa selain sumber daya finansial, sumber daya manusia merupakan salah satu faktor esensial yang menentukan 
keberhasilan organisasi dalam mencapai tujuannya.

Fakta lapangan menunjukan bahwa di Kabupaten Ciamis sendiri dalam upaya implementasi Peraturan Bupati No 51 Tahun 2014 Tentang Pendirian Toko Modern Serta Perlindungan Usaha Kecil, Warung/Toko Dan Pasar Tardisional, secara langsung melibatkan banyak Satuan Kerja Perangkat Daerah, di antaranya meliputi : (1) Dinas Koperasi, UKM, Perindustrian dan Perdagangan, (2) Satuan Polisi Pamong Praja, (3) Badan Pelayanan Perizinan Terpadu dan Penanaman Modal dan (4) Dinas Cipta Karya, Kebersihan dan Tata Ruang. Sub bidang kerja keseluruhan organisasi tersebut saling bersinggungan dalam kaiatannya dengan upaya penataan minimarket di Kabupaten Ciamis

Dapat ditelisik secara sederha keseluruhan pada organsasi tersebut secara prinsipnya masih mengalami berbagai permasalahan pada tataran internal organisasi. Berdasarkan hasil penelitian bahwa baik dari kualitas dan kuantitas berbagai organisasi di atas masih belum melaksanakan fungsinya secara optimal terkait dengan sub kerja dalam penataan minimarket di Kabupaten Ciamis. Sebagai contoh: Dinas Koperasi, UKM, Perindustrian dan Perdagangan bahwa minimnya personil dalam pelaksanaan tugas dan fungsi suatu organisasi menjadi kendala dan alasan klasik yang belum mendapat perhatian serius pemerintah, bahwasanya $30 \%$ dari pegawai yang ada adalah personil dengan status honorer. Perbedaan status tersebut secara langsung berpengaruh terhadap motivasi kinerja pegawai (man) dalam mencapai tujuan organisasi.

Pada aspek organisasi berbicara tentang penetapan atau pengaturan sumber daya, unit dan metode-metode untuk menjadikan kebijakan berjalan efektif. Bahwasanya berkaitan dengan pengimplemntasian Peraturan Bupati Nomor 51 Tahun 2014 Tentang
Pendirian Toko Modern Serta Perlindungan Usaha Kecil, Warung/Toko Dan Pasar Tardisional, dapat dikatakan sumber daya organisasi terutama pada tataran sumber daya manusia di Dinas Koperasi, UKM, Perindustrian dan Perdagangan hanya dapat optimal ketika berususan dengan pekerjaan bersifat administrasi, rutin dan teknis.Dengan masih rendahnya kemampuan sumber daya manusia di SKPD sebagai unit pelaksana peraturan daerah tersebut, dapat dipastikan pelaskanaan penataan minimarket hanya baru hanya sebatas niatan baik tanpa tindakan nyata secara oprasional. Disatu sisi pemerintah daerah belum melakukan upaya yang maksimal bagi pegawai untuk meningkatkan kualitas aparatur di SKPD secara menyeluruh guna megoprasionalkan pekerjaan-pekerjaan yang sifatnya membutuhkan analitis dan kreativitas yang sangat diperlukan dalam tindakan implementasi regulasi Tentang Pendirian Toko Modern Serta Perlindungan Usaha Kecil, Warung/Toko Dan Pasar Tardisional.

Minimnya kemampuan sumber daya manusia (SDM) pada dinas yang mejadi sektor terdepan dalam pengimplemetasian penataan minimarket di Kabupaten Ciamis merupakan permasalahan besar yang idealnya mendapat perhatian serius kerena berkaitan erat dalam mencapai tujuan organisasi. selain dukungan sumber daya lainnya seperti finansial, sarana dan prasarana alatyang memadai. Kebutuhan sumber daya manusia merupakan permasalahan yang tidak kian mendapat pembenahan meskipun menduduki posisi strategis dalam menentukan kredibilitas organisasi. Mengutip dari (Ndraha, 2012) bahwasanya sumber daya manusia adalah "penduduk yang siap, mau dan mampu memberi sumbangan terhadap usaha pencapaian tujuan organisasional".

Dampak berkelanjutan dari lemahnya SDM adalah kegagalan dalam memanfaatkan sumber daya serta 
membuat unit-unit fungsi khusus dalam organisasi juga menjadi sebab lain tidak terlaksananya penataan minimarket dan pelaksanaan zonasi sebagaimana mesinya. Besarnya tugas pokok fungsi kelembagaan yang mengurusi bidang perdagangan, koperasi, industri maupun UKM sebagaimana dalam struktur pemerintahan Kabupaten Ciamis menyebabkan tidak adanya fokus dalam bidang penataan minimarket.Ihwal tersebut salah satu yang menyebabkan penataan mimimarket di Kabupaten Ciamis khususnya tidak menjadi program kerja dinas secara terarah.

Menyambung dari pada itu, multi organsasi yang berupaya mengakomodir implementasi pernataan imimarket di Kabupaten Ciamis sangat beragam sehingga secara langsung menimbulkan adanya tumpang tindih dan ketidakselarasan dalam pengimpelemtasian Peraturan Bupati No 51 Tahun 2014 Tentang Pendirian Toko Modern Serta Perlindungan Usaha Kecil, Warung/Toko Dan Pasar Tardisional.Ditelisik berdasarkan fungsi beberapa SKPD tersebut bahwa: Dinas Koperasi, UKM, Perindustrian dan Perdagangan bertugas dalam perumusan kebijakan teknis tentang penataan minimarket dan penetapan zonasi minimarket, penyelenggaraan sebagian urusan pemerintahan dan pelayanan umum penataan minimarket dan penetapan zonasi, pembinaan dan pelaksanaan tugas di bidang usaha minimarket.

Sedangkan Badan Pelayanan Perizinan Terpadu dan Penanaman Modal dalam hal pelaksanaan koordinasi dan menyelenggarakan pelayanan administrasi di bidang perizinan minimarket, penyelenggaraan administrasi perizinan minimarket, pelaksanaan koordinasi proses pelayanan perizinan minimarket, pemantauan dan evaluasi proses pemberian pelayanan perizinan minimarket dan pemberian dukungan atas penyelenggaraan pemerintahan daerah di bidang penanaman modal pada sektor minimarket.

Sedangkan Dinas Cipta Karya, Kebersihan dan Tata Ruang meliputi penyelenggaraan sebagian urusan pemerintahan dan pelayanan umum di bidang penataan ruang serta pembinaan dan pelaksanaan tugas bidang perumahan, persampahan dan pertamanan. Serta Satuan Polisi Pamong Praja yang fokus dalam penyusunan program dan pelaksanaan penegakkan Perda dan Peraturan Kepala Daerah terkait dengan minimarket, penyelenggaraan ketertiban umum dan ketenteraman masyarakat serta perlindungan masyarakat, pelaksanaan kebijakan penegakkan Perda dan Peraturan Kepala Daerah terkait dengan minimarket.

Berdasarkan hasil penelitian di lapangan bahwa banyaknya unit organisasi yang terpisah yang memiliki peran dalam penataan minimarket berdampak pada efisiensi dan efektifitas yang dalam tataran pelaskanaannya menimbulkan tumpang tindih yang bersifat destruktif dari akibat lemahanya koordinasi yang ada. Pada akhirnya berdampak lemahnya penyelenggaraan penataan minimarket berujung tidak berjalannya peraturaan dan fungsi organisasi yang terlibat. Sesuai dengan pernyataan(Jones, 1996) bahwa "variasi yang luas dari organisasi dapat menyiratkan bahwa kedudukan suatu program dapat menghasilkan perbedaan dalam penerapannya".

(Dunn, 2003) menyampaikan bahwa kebijakan publik itu pada dasarnya dilakukan oleh unit-unit administrasi yang memobilisasi sumberdaya finansial dan manusia Karena besarnya sumberdaya yang akan dikelola, luasnya aspek dan bidang pekerjaan yang akan diimplementasikan serta banyaknya pelaksana kebijakan yang dilibatkan maka diperlukan adanya unit-unit organisasi. Unit organisasi tersebut dibentuk untuk membuat spesialisasi-spesialisasi fungsi sehingga 
sektor-sektor serta kegiatan-kegiatan yang akan dilaksanakan dapat lebih terfokus.

Kondisi di atas akan terpenuhi ketika kualitas sumber daya manusia (SDM) dalam organisasi terpenuhi (profesional) berbalut tingkat koorinasi yang tinggi. Ihwal tersebut tidak terbukti ketika dihadapkan dengan lemahnya sumber daya manusia yang terlibat, seperi dalam konteks penelitian dalam penataan minimarket di Kabupaten Ciamis yang berdasarkan aspek organisasi memiliki kualitas dan kuantitas SDM yang tidak memadai. Terlihat dari menjamurnya minimarkat yang tidak berizin, fakta di lapangan menunjukan terdapat sepuluh (10) unit mimimarket baik terdiri dari Alfamart dan Indomart "bodong" atau tak berizintelah beroprasional selama bertahun-tahun yang ditinjau dari keberadaannya berhimpitan dengan pasar tradisonal dan toko kelontong.

Pengawasan baik dari tataran awal perizianan, penerbitan izin mendirikan bangunan, dan pemberian izin usaha secara aplikatif tidak berjalan. Tidak dipungkiri banyaknya pengusaha yang "nakal dan bermain". yang mengurus administrasi perizianan setelah usaha mereka beroprasional. Kegagalan tersebut selaras dengan tumpang tindihnya kewenangan sehingga memunculkan saling lempar tanggung jawab antar organisasi.

\section{Dimensi Interpretasi : Lemahnya artikulasi penyelenggara Penataan Minimarket}

Interpretasi atau penerjemahan bermakna bahwa pelaksana kebijakana harus mampu menjalankan program sesuai dengan petunjuk teknis dan petunjuk pelaksana sebagai arah untuk mencapai tujuan yang diharapkan. Interpretasi juga berbicara tentang penerjemahan bahasa program yang biasanya dibuat dalam statuta organisasi yang akseptable, rencana kelayakan dan arah dari program.
Lemahnya interpretasi menyebabkan timbulnya ketidaktegasan aktor penyelenggara kebijakan publik tersebut bedampak pada jaminan kelangsungan pasar dan pedagang terdisonal. Namun disatu sisi tidak dipungkri kebermanfaatan keberadaan minimarket ketika ditunjau dari pemasukan bentuk pandapatan asli daerah (PAD). Karena di Kabupaten Ciamis sendiri terdapat 6 superarket,73 minimarket jaringan dan 9 minimarket non jaringan, yang memberi sumbagsih PAD kurang lebih sebesar 1 milyar.

Berbanding terbalik dengan pertumbuhan minimarket di Kabupaten Ciamis. Berdasarkan penelitian di lapangan bahwa sangat disayangkan Penataan dan penetapan zonasi minimarket dalam perencanaan kinerja Satuan Kerja Perangkat Daerah (SKPD) khususnya Dinas Perdagangan dan UKM Kabupaten Ciamis tidak menjadi prioitas sebagai program kerja tersendiri. Ihwal tersebut sangat bertolak belakang dengan program daerah yang optimis meningkatkan pertumbuhan ekonomi daerah melalui peningkatan pendapatan daerah (PAD). Tidak mengherankan jika pada akhirnya Implementasi kebijakan penataan minimarket dan penetapan zonasi minimarket di Kabupaten Ciamis dalam hampir satu dekade terakhir tidak luput dari beragam masalah, dalam bentuk pelanggaran.

Perda Kabupaten Ciamis Nomor 18 Tahun 2018 serta Perbup Ciamis Nomor 51 Tahun 2014 merupakan sebuah produk kebijakan publik yang perlu diperhatikan eksistensinya dan kesesuaian materi muatannya dengan perkembangan dan dinamika yang mewarnai implementasi penataan minimarket dan penetapan zonasi minimarket tersebut. Sayangnya penataan minimarket sendiri belum menjadi prioritas pemerintah daerah Kabupaten Ciamis, hal tersebut berkorelasi terhadap perencanaan yang matang mengenai penataan minimarket berdampak terhadap hadirnya 
minimarket tak izin atau pelaku usaha yang menyalahgunakan izin.

Lemahnya

perencanaan

berbanding lurus dengan iterpretasi dalam mengartikan sebuat program kebijakan. Hal tersebut sesuai dengan (Mazmanian, Daniel H., 1983) yang mengemukakan bahwa dalam melakukukan impelementasi kebijakan terdapat tiga yang harus dilakukan yaitu: 1. identifikasi masalah yang harus diintervensi, 2. menegaskan tujuan yang hendak dicapai, dan 3. merancang struktur proses pelaksanaan.

Pernyataan Mazmanian dan Sebatier dapat mengkonfirmasi permalahan di lapangan, hal tersebut terbukti dengan belum singkronnya tujuan pemerintah daerah dengan regulasi yang ditetapkan saat ini, wajar adanya ketika dalam pelaksanaan masih banyak interpretasi yang tidak sejalan antar aktor pelaksana. Idealnya dalam pelaksanaan kebijakan penataan minimarket yang notebene melibatkan banyak aktor di dalamnya sangat memerlukan konsistensi keterikatan bersama terhadap keberlangsungan mencapai tujuan kebijakan mulai dari RPJMD sampai kepada target dinas/SKPD. Dalam hal ini selain konsistensi, pengawasan oleh pihakpihak berkepantingan menjadi sebuah titik krusial. Artinya lemahnya pengawasan berdampak pada disensus atau pelanggaran dari tujuan awal. Banyaknya oknum-oknum otomatis akan berdampak pada kegagalan produk yang pada akhirnya akan merugikan masyarakat sebagai sasaran kebijakan.

Sebagai bukti terdapatnya mimimarket yang telah beroprasional namun dalam perzinan administrasinya hanya menggunakan izin mendirikan bangunan (IMB) tanpa adanya surat izin usaha (SIUP) dan ketika melihat letak minimarket tersebut sejatinya telah melanggar Peraturan Bupati No 51 Tahun 2014 Tentang Pendirian Toko Modern Serta Perlindungan Usaha Kecil, Warung/Toko Dan Pasar Tardisional.
Lemahnya intrepretasi berbandung lurus dengan lemahnya intervensi, ihwal tersebut membuat penyelengara pemerintah mau tidak mau melakukan pembiran terhadap kondisi tersebut dengan alasan "kasihan karena sudah dibangun dan beroprasional masa kita tutup" terpaksa melegalkan minimarkat tersebut. Artinya ketidaktegasan dan lemahnya konsistensi dalam menginterpretasikan sebuah regulasi bagi pemagku kepentingan merupakan bencana berdampak gagalnya regulasi yang telah dibuat.

Hasil penelitian menyebutkan kegagalan kebijakan penataan minimarket di Kabupaten Ciamis selain dari lemahnya interpretasi dan ketegasan serta konisitensi terdapat pula nepotisme dalam penegakan peraturan tersebut, adanya hubungan kekerabatan antara pengusaha dengan penguasa (oknum dalam SKPD) menjadikan beberapa minimarket yang melanggar aturan bebas berdiri melangsungkan usahanya.

Sesuai dengan (Jones, 1996) bahwa "problematika birokrasi secara umum memiliki tujuan awal yang dirancang menjalankan program, akan tetapi terdapat tujuan bersama lain sehubungan munculnya motivasi lain seperti mengembangkan diri". Artinya kembali lagi bahwa faktor akuntabilitas sumber daya manusia (SDM) sangat menentukan diberbagai aspek dalam implementasi kebijkan. Kondisi tersebut mengisyaratkan perlunya reformasi kelembagaan khususnya dalam peningkatan skill dan kompetensi SDM yang profesional, dengan menerapkan pengawasan ketat, dan adanya tindakan tegas dari pelanggaran yang dilakukan oleh oknum terkait, hal tersebut sekaligaus menjadi rujukan kembali (evaluasi) terhadap kebijakan yang akan diterbitkan dimasa mendatang.

\section{Dimensi aplikasi : Minimnya Pencapaian Tujuan Regulasi}


Aplikasi atau penerapan berbicara tentang pembuatan prosedur kerja yang jelas agar program kerja dapat berjalan sesuai dengan jadwal kegiatan (timetable) sehingga tidak berbenturan dengan program lainnya. Aplikasi juga berbicara tentang syarat layanan, pembayaran atau kesepakatan lainnya yang sesuai dengan tujuan dan instrumen. (Jones, 1996) menyampaikan bahwa produk dari implementasi kebijakan itu selain pelayanan adalah pembayaran, kemudahan dan pengawasan. Oleh karenanya para pelaksana kebijakan jangan memandang bahwa produk kebijakan tersebut hanya merupakan bagian dari kegiatan administratif. Kemudahan sebagai bagian dari produk kebijakan tersebut idealnya juga dikedepankan, karena publik sebagai konsumen dapatmerasa tidak puas terkait dengan layanan yang diberikan oleh pelaksana kebijakan.

Dalam konteks penelitian implementasi Peraturan Bupati Nomor 51 Tahun 2014 tentang Pendirian Toko Modern serta Perlindungan Usaha Kecil, Warung/Toko dan Pasar Tardisional, peneliti berfokus terhadap aspek regulasi sebagai sebuah point krusial. Terkait dengan pelaksanaan Perbup tersebut secara administratif formalis selaras dengan Peraturan Presiden Nomor 112 Tahun 2007 Tentang Penataan dan Pembinaan Pasar Tradisional Pusat Perbelanjaan dan Toko Modern, yang melihat bahwa pasar moderen termasuk didalamnya minimarket perlu dilakukan penataan karena dengan semakin berkembangnya usaha perdagangan eceran dalam skala kecil dan menengah, usaha perdagangan eceran modern dalam skala besar, maka pasar tradisional perlu diberdayakan agar dapat tumbuh dan berkembang serasi, saling memerlukan, saling memperkuat serta saling menguntungkan.

Selain itu pada Pasal 4 Perpres 112 Tahun 2007 tersebut dijelaskan bahwa pendirian pusat perbelanjaan dan toko modern wajib memperhitungkan kondisi sosial ekonomi masyarakat, keberadaan pasar tradisional, usaha kecil dan usaha menengah yang ada di wilayah yang bersangkutan; memperhatikan jarak antara hypermarket dengan pasar tradisional yang telah ada sebelumnya. Berdasarkan hal tersebut posisi peraturan Bupati Ciamis No 51 Tahun 2014 dalam penataan minimarket memiliki standar pendukung atau regulasi di atasnya. Namun sangat disayangkan ketika kuatanya formalitas tersebut terbantahkan akibat lemahnya aktor pelaksana berbalut konsistensi yang rendah. Artinya regulasi yang telah dilaksanakan saat ini bersifat formalitas tanpa memberikan kepastian hukum di tegah-tengah masyarakat.

Ketidakpastian hukum di tengahtengah masyarakat bardampak ketidakpercayaan masayarakat akan kinerja pemerintah daerah tak terkecuali penataan minimarket.Idealnya pemerintah sebagai pembuat kebijakan dapat memastikan keterlibatan aktif lembaga-lembaga yang bersinggungan dengan penataan minimarket di Kabupaten Ciamis. Dalam Penataan minimarket di Kabupaten Ciamis berdasarkan hasil pelitian belum adanya analisa yang kuat baik oleh kepala daerah maupun lembaga legislatif terhadap permasalahan yang timbul di lapangan. Permasalahan yang timbul di lapangan sendiri pada tatarannya berada pada ketegasan aparatur dalam menjalankan peraturan yang berlaku, terbukt dengan beroprasinya 10 minimarket tanpa izin.

Hasil penelian di lapangan menunjukan berkembangnya iklim usaha salah satunya dipengaruhi oleh kebijakan yang memiliki fungsi aplikatif. Hal tersebut berkaitan erat dengan kemampuan sistem yang dibangun,sedangkan sistem yang dibangun terkait dengan banyak pelaku dan faktor yang berpengaruh nyata serta bersifat jangka panjang (multies years). Tidak dipungkiri pedangang tradisioal termasuk usaha mikro kecil menengah 
(UMKM) sebagai basis pembangunan daerah masih dihadapkan pada banyak masalah antara lain: a) Rendahnya Produkfitas berdampak pada timbulnya kesenjangan antara UMKM dengan usaha besar, b) Terbatasnya akses sumberdaya produktif seperti permodalan, teknologi, pasar dan informasi, c) Tidak kondusifnya iklim usaha yang dihadapi. Ketiga permasalahan tersebut dapat ditasi dengan inovasi dan kreatifias yang dimanifaestasikan dengan penataan melalui Peraturan Daerah (Perda) untuk mendukung pemberdayaan, penataan serta penyempurnaan Peraturan Perundang-undangan yang berkaitan dengan pengembangan UMKM dan pentaan pasar modern termasuk minimarket.

Bertalian dengan hal di atas, terdapat kesulitan pemerintah daerah dalam melakukan pengawasan dalam implementasi penataan minimarket tidak telepas dari fakta bahwa unit-unit yang dibentuk oleh pemerintah daerah yang membidangi masalah penataan minimarket belum bekerja secara integratif (terintegrasi-singkronisasi) menyebabkan sulitnya esensi pencapaian tujan yag dimaksud dalam peraruran Bupati Ciamis Nomor 51 Tahun 2014. Dapat ditelisik lebih dalam bahwa esensi arah kebijakan Perbup tersebut yaitu guna melakukan pemberdayaan pasar tradisional agar dapat tumbuh dan berkembang serasi, saling memerlukan, saling memperkuat, serta saling menguntungkan memberikan akselerasi pengetahuan bagi penyelenggaraan ritel tradisional, pusat perbelanjaan, dan toko modern, memberikan norma-norma keadilan terhadap berbagai pihak, saling menguntungkan dan tanpa tekanan dalam hubungan antara pemasok barang dengan toko modern, pengembangan kemitraan dengan usaha kecil, sehingga tercipta persaingan dan keseimbangan kepentingan produsen, pemasok, toko modern dan konsumen.

Dalam mencapai tujuan di atas, pengawasan secara komprehensif sangat diperlukan, artinya dalam penyediaan berbagai macam layanan harus mendapat pengawasan di tataran lapangan. Karena di Kabupaten Ciamis dari 10 minimarket ilegal/tak berizin atau bermodal izin mendirikan bangunan(IMB) yang telah beroprasi berawal dari ketidak jujuran pemohon. Artinnya kepengurusan izin tersebut dilakukan setalah toko/minimarket tersebut beroprasional, di samping adanya ketidak jujuran saat melakukan pengususan surat izin usaha (SIUP).

Guna meminimalisir kasus di atas terus berulang, pemerintah Kabupaten Ciamis secara berkala telah melakukan pembinaan khususnya kepada pelaku usaha untuk memberikan keterangan yang sesuai mengenai usaha yang akan di laksanakan. Diakui oleh jajaran dalam SKPD bahwa perilaku“nakalnya"pengusaha minimarket yang ada di Kabupaten Ciamis membuat pemerintah kesulitan dalam melakukan pengawasan. Penyalahgunaan rekomendasi perizinan kerap kali dilakukan guna melancarkan usahanya berujung menjamurnya minimarket tanpa izin.

Berdasarkan hemat peneliti idealnya pemerintah bertindak tegas dengan segala bentuk pelanggaran terkait administrasi yang telah dilanggar, terlebih usaha minimarket yang melanggar tersebut posisinya berhimpitan dengan warung kelontong milik masyarakat. Keberadaan minimarket tersebut lambat laun akan mengancam dan mematikan keberlangsungan usaha kerakyatan yang menjadi penopang guna mengidupi kebutuhan diri dan keluarga. Di lain sisi posisi Polisi PamongPradjasebagai penegak Peraturan Daerah idealnya memiliki pengetahuan yang cukup, tidak tebang pilih dan profesional dalam melakukan penindakan sesuai dengan peraturan yang berlaku. 


\section{Kesimpulan}

\begin{tabular}{ccc}
\multicolumn{2}{c}{ Berdasarkan } & hasil dan \\
pembahasan pada penelitian & ini
\end{tabular} kemampuan Pemerintah Daerah Kabupaten Ciamis dalam mengimplentasikan Peraturan Bupati Kabupaten Ciamis No 51 Tahun 2014 Tentang Pendirian Toko Modern Serta Perlindungan Usaha Kecil, Warung/Toko Dan Pasar Tardisional masih benyak memiliki kelemahan, terutama berada pada tataran kualitas aktor di samping masih terdapatnya kekurangan di beberapa SKPD seperti yang terjadi pad Dinas Koperasi, UKM, Perindustrian dan Perdagangan. Penataan minimarket di Kabupaten Ciamis semakin menemui titik sulit karena terdapatnya fungsi dan kewenangan yang tuumpang tindih dan cenderung memiliki koordinasi, komunikasi dan sinergi yang rendah.

$\begin{array}{lcr}\quad \text { Hal } & \text { tersebut } & \text { berdampak } \\ \text { terhadap } & \text { sulitnya } & \text { upaya-upaya } \\ \text { pemerintah } & \text { dalam } & \text { melakukan }\end{array}$
pengawasan, penataan, pembinaan, dan penegakan yang sesuai dengan Peraturan Bupati Kabupaten Ciamis Nomor 51 Tahun 2014 Tentang Pendirian Toko Modern Serta Perlindungan Usaha Kecil, Warung/Toko Dan Pasar Tardisional.

Dilain sisi masih terdapat pengusaha minimarket "nakal", hal tersebut merupakan tantangan tersendiri bagi pemerintah Kabupaten Ciamis dalam upaya menselaraskan tujuan peningkatan Pendapatan Asli Daerah melalaui sektor tersebut, di samping tetap berorientasi menjaga keberlangsungan pasar tradisonal dan warung kelontong sebagai salah satu basis ekonomi kerakyatan yang harus dijaga eksistensinya. Mencermati kondisi tersebut bahwasanya pemerintah daerah Kabupaten Ciamis perlu melakukan deregulasi tehadap Peraturan Bupati Nomor 51 Tahun 2014 sebagai langkah kongkrit perbaikan terhadap kondisi dimasa mendatang.

\section{Acknowledgment}

Penelitian ini dapat terlaksana berkat bantuan Fakultas Hukum dan Sosial Program Studi Ilmu Pemerintahan Universitas Mathla'ul Anwar Banten yang telah mendanai penelitian dan publikasi artikel ini. Untuk itu saya mengucapkan terima kasih kepada dekan, kaprodi Ilmu pemerintahan dan rekan-rekan dosen tetap yang telah mendukung dan membantu kegiatan penelitian ini.

\section{Daftar Pustaka}

Arno, A. K., \& Aqidah, N. A. (2018). Zonasi Mini Market di Kota Palopo: Suatu Tinjauan Upaya Perlindungan Pasar Tradisional dan Warung Kecil. AlAmwal : Journal of Islamic Economic Law, 3(2), 198-210.

Bungin, B. (Ed.). (2012). Analisis Data Penelitian Kualitatif: Pemahaman Filosofis dan Metodologis ke Arah Penguasaan Model Aplikasi. Jakarta: Raja Grafindo Persada.

Creswel, J. W. (2015). Penelitian Kualitatif \& Desain Riset: Memilih Diantara Lima Pendekatan. Yogyakarta: Pustaka Pelajar Bintoro.

Dunn, W. N. (2003). Pengantar Analisis Kebijakan Publik edisi kedua. Yogyakarta: Gajah Mada University Press.

Jones, C. O. . (1996). Pengantar Kebijakan Publik. Jakarta: Rajawali.

Mazmanian, Daniel H., P. A. S. (1983). Implementation and Publuc Policy. New York: Harper Collns.

Moleong, L. (2008). Metodologi Penelitian Kualitatif. Bandung: Remaja Rosdakarya.

Ndraha, T. (2012). Pengantar teori 
Pengembangan Sumber Daya Manusia. Jakarta: Rineka Cipta.

Agustino, Leo (2008)Dasar- Dasar Kebijakan Publik. Bandung: Alfabeta

Dwidjowijoto, Riant Nogroho (2000) Otonomi Daerah: Desentralisasi Tanpa Revolusi, Kajian dan Kritik atas Kebijakan Desentralisasi di Indonesia. PT Elex Media Komputindo, Kelompok Gramedia: Jakarta.

Jones, Charles O (1991) Pengantar KebijakanPublik (Terjemahan), Jakarta: Rajawali

\section{PeraturanPeundang-Undangan}

Undang Undang Nomor 23 Tahun 2014 tentang Pemerintahan Daerah

Peraturan Presiden Nomor 112 Tahun 2007 Tentang Penataan dan Pembinaan Pasar Tradisional, Pusat Perbelanjaan, dan Toko Moderen

Peraturan Bupati Ciamis Nomor 51 Tahun 2014 Tentang Pendirian Toko Moderen Serta Perlindungan Usaha Kecil, Warung/Toko dan Pasar Tradisional. 